\title{
An Exploration of Factors Influencing Career Progression of Tutors in Public Primary Teachers' Training Colleges in Kenya
}

\author{
Peter N. Muchanje ${ }^{1, *}$, Felicita W. Njuguna ${ }^{2}$,Jeremiah M. Kalai ${ }^{3}$, Sophia M. Bironga ${ }^{4}$ \\ ${ }^{1}$ International Centre for Capacity Development, Kenyatta University, Kenya \\ ${ }^{2}$ School of Education, Kenyatta University, Kenya \\ ${ }^{3}$ School of Education, University of Nairobi, Kenya \\ ${ }^{4}$ Department of Education, Kenya Technical Teacher Training College, Kenya
}

Copyright $\bigcirc 2016$ by authors, all rights reserved. Authors agree that this article remains permanently open access under the terms of the Creative Commons Attribution License 4.0 International License

\begin{abstract}
The study sought to determine the influence of gender, Teachers Service Commission (TSC) adherence to career progression policy guidelines and tutors' exposure to professional development on career progression of tutors in primary teachers training colleges in Kenya. This study was a descriptive survey with 264 tutors randomly sampled from eight Public Primary Teacher Training Colleges. Out of the 264 sampled, 207 tutors returned the questionnaires for analysis. Data was collected using a questionnaire for tutors, interview schedule for Principals and TSC officers. One way Chi-square and linear regression analysis (at $\alpha=0.05$ level of significance) were used to test the relationship between each variable and tutors career progression. The study found that gender was not significantly related to tutors' career progression. Further analysis revealed that exposure to professional development influenced tutors career progression positively. The study concluded that tutors' gender did not have any significant relationship with career progression. However, exposure to professional development and adherence to policy guidelines by TSC influenced career progression positively, which is positive result for this study. The study recommended that there is also need to increase the number of appointive positions in Primary Teacher Training Colleges to provide tutors with more chances of career progression. Above all the study recommended that tutors should be regularly exposed to professional development so as to update their skill and competence.
\end{abstract}

Keywords Tutors, Career Progression, Public Teacher Training Colleges, Gender, Professional Development and Career Policy

\section{Introduction}

Career progression affects all facets of organization lives.
Both employees and employers often view career progression in different dimensions. While employees see career growth prospects as a chance to find motivation in their work place and increase their financial security (Okurame, 2012) employers see it as a source of resource strain and employee competitive process (Hall, 1996). Whichever way it is looked at, career progression is an essential source of motivation to workers as moving up an organization hierarchy through promotion. It increases an employee's motivation to have a strong involvement in organization and career activities (Lunenberg, 2011, Ballout, 2009, Mello, 2006, Smollin, 2011; O'Reilly \& Chatman 1986). Research shows that increased career prospects is accompanied by job effectiveness (CIPD 2006), reduced absenteeism (Okurame 2014), willingness to remain in the organization (Weer, 2009 and Mugo 2010) and reduced unrests (Meyer \& Allen, 1984, Okurame 2012). Kenya is one of the developing countries that put education in the forefront in order to achieve development goals. According to Teachers Service Commission (2009), tutors especially those teaching in colleges are discouraged due to low remuneration and stagnation in one job group. This is despite the fact that college tutors form a broad back bone of education system without which the teaching force especially in primary schools would be wanting (Rivkin et al, 2000, Uwezo, 2011). Tutors are therefore an important resource in teaching/learning process and their career progression therefore requires critical consideration. This stagnation according to Charamie, Sturman and Walsh (2007) may cause dissatisfaction which may lead to reduction of productivity in the work place, decrease in organizational commitment and even worse leaving for greener pastures.

Given the importance of career progression, it is surprising that few studies have attempted to examine the role of gender and professional development in shaping career progression of PTTC tutors in Kenya (Zinn, 1997; Goodland, 1984; Powell \& Butterfield, 1994; Okurame, 
2012). This study attempted to fill this gap and to explore what affects career progression in PTTCs in Kenya.

\section{Purpose of Study}

The purpose of this study was to explore the lived experiences and perceptions of all 756 tutors in Public Primary Teacher Training Colleges in Kenya, to better understand the factors they perceived to be contributors or barriers to their career progression.

\section{Objectives of the Study}

The study used three broad objectives:

i. To determine the influence of tutors' gender on tutors career progression in primary Teachers Training Colleges

ii. To establish the impact of exposing tutors to professional development on career progression of tutors in primary teachers' training colleges in Kenya

iii. To establish the relationship between TSC adherence to policy guidelines and tutors career progression

\section{Method}

The study targeted all the 18 Primary Teacher Training Colleges (PTTCs) and 756 tutors at the time of study. There are 21 public primary teacher training colleges in the republic but at the time of the study, there were 18 Primary Teachers' Training Colleges (PTTCs) that had presented candidates for Primary Teacher Education examinations. A sample of 264 participants determined statistically using a combination of stratified sampling and simple random sampling was used. To get the total number of tutors to be included in the study, Yamane formula (Trochim, 2009) was used. This formula was most appropriate to this study since the population was below 1500. Data was collected through a questionnaire for tutors containing measures of demographic information and career progression factors and interview schedule for principals and TSC officials Validity was ensured through a pretest in one college. Reliability was measured using Spearman Rank correlation Coefficient which stood at 0.725 . Quantitative data was analysed using regression analysis, Chi-square and ANOVA. Qualitative data was analysed by using Miles \& Haberman (1994) guide.

\section{Literature Review}

Achieving gender equality at all levels is a growing concern among both developing and developed countries. Researchers like (Gallos, 1989, Cox and Cooper, 1998, Hakim, 2006, Linge, Willie and Damary, 2010) feel that women who have been given challenging assignments performed well therefore improved their chances of career advancement. This put women in equal probability of rising up the ladder of leadership as men in teaching profession. However, other researchers have pointed out stagnation of women in their career which has become an increasing important and concerning issue (Wanjama, 2002, Ismael \& Arokiasamy, 2007, SECMEQ, 2010, Mwangi, 2011 and Tudor, 2013). These researchers agree that there are disparities in career progression of tutors in various academic levels with men performing better than women. They felt that some of the factors that lead to women's career advancement include mentoring, training and development, career planning, individual characteristics and hard work. Research conducted by Southern and Eastern Consortium for Monitoring Educational Quality (SECMEQ, 2010) for example, indicated that about two thirds of teachers involved were female teachers but only $21 \%$ of these women teachers are heads in developing countries including Kenya. These figures may have two implications on this research. First female teachers may consider that there are barriers to their career advancement which may imply gender discrimination. Secondly, the gender inequalities could send wrong signals to pupils that female teachers are incapable of being leaders which may affect girl child's career aspirations.

Hiring and promotion policy should be clearly stated in every organization so that workers know the correct path to follow (Lacey, 2001, Armstrong, 2009 and Okurame 2012). According to these researchers policies should be put in place to deliberately train managers for the future. Since the launch of free primary education (FPE) in 2003 in Kenya, there has been an upsurge in the enrollment in public primary schools. As a result, there has been a high demand for more teachers (Ministry of Education Science and Technology (MOEST), 2005) who are trained in PTTCs. The tutors here require promising policies which guarantee them career progression prospects. According to TSC (2009), career progression of tutors in PTTCs is the same as that of teachers teaching in secondary schools. As outlined in policy documents (MOEST, 2005, TSC, 2006 and TSC, 2007 and), graduate teacher enters teaching profession under TSC in Kenya at job group $\mathrm{K}$. After three years, the teacher is automatically promoted to job group L. For the teacher to move to the next job group up to job group $\mathrm{R}$ the highest in teaching profession in Kenya, he/she must have served in the current job group for a minimum of three years and passed an interview conducted by TSC. Job group M is the start of administrative positions with TSC. However according to Republic of Kenya (2012), TSC promotes tutors on the basis of availability of funds, meaning a tutor can remain in one job group especially lower job groups for more than three years.

With increasing emphasis on accountability, it is important that teachers are not just equipped as they enter teaching but continually develop their career (Hughes, 1991). Government of Kenya (2005) committed all public agencies including PTTCs in cost saving as their targets in their performance contracting. One incongruity of this situation is that institutions budgets for human resource development are often the first to be cut. This makes it difficult for tutors to have smooth career progression. The importance of Professional development of tutors to career progression 
therefore is hampered. An evaluation done by Brown and Sumra (1999) on East African Madrasa programme summed the importance of professional development to career progression of tutors. They asserted that professional development reinforced graduate training and sharpened skills for leadership

\section{Results}

Out of a total of 264 tutors who were given questionnaires, a total of 207 successfully completed and returned; translating to a response rate of 78.4 per cent. This was favourable according to Mugenda and Mugenda (2003) in which they assert that a $50 \%$ response rate is adequate, $60 \%$ response rate is good and above $70 \%$ response rate is very good.

\section{Gender and Career Progression}

Tutors respondents by gender were almost evenly distributed with $52.2 \%$ male and $47.8 \%$ female. This again contradicted Lacey (2004), who concluded that in many institutions of learning in many countries there are more female tutors than male tutors. More than half of sampled representing female tutors (78\%) who responded to the questionnaire said that family ties do not influence to a large extent the upward movement of tutors in colleges.

Further analyses indicated that there were three male Deans sampled compared to two female Deans in the sample. Comparatively, out of the sixteen Principals interviewed, only six were female Principals. A further analysis showed that there were twelve men Heads of Department (HODs) and twenty eight men Heads of Subject (HOSs) compared to fifteen women HODs and nineteen women HOS. This comparatively showed no preference on any gender of tutors in PTTCs.

$\mathrm{H}_{01}$ : There is no significant relationship between tutors gender and their career progression.

To test if gender has influence on tutor's career progression, a Chi - square test for association was applied on the variables and results summarized in Table 1.

Table 1. Association between tutors gender and career progression.

\begin{tabular}{|c|c|c|c|}
\hline & Value & DF & Asymp.sig (2- sided \\
\hline Pearson Chi - square & 37.04 & & \\
Nominal by Nominal Phi & 0.426 & \multirow{2}{*}{35} & 0.375 \\
Cramer's V & 0.426 & & \\
Number of valid cases & 207 & & \\
\hline
\end{tabular}

56 cells $(77.8 \%)$ have expected count less than 5 . The minimum expected value is 48 .

Chi - square for association between tutors gender and their career progression is insignificant $\left(X^{2}=37.04, d f=35\right.$, $p>0.05)$. The observed distribution of data compared to the expected distribution based on the null hypothesis indicates lack of existence of significant differences. The study accepted the null hypothesis and conclusion made that gender did not have influence on career progression of tutors in PTTCs. However, Cramer's V was equal to 0.426 which shows a moderate relationship between gender and career progression of tutors in PTTCs. This means that no preference is given to a particular gender since gender representation is even. This was a surprising result as ordinarily one would expect that there is gender difference in career progression of tutors especially young nursing mother tutors.

Other authors (Gallos, 1989; Hakim, 2006) who have discussed the role of gender in shaping individual career and the differences that can be found between men and women in their careers agree with this conclusion, that gender differences may exist though relationships is not notable. Although Hakim admits that the social and economical context can have some influence, lifestyle preferences are certainly the principal determinants on women career choice. However, other researchers like Burke (2007) and Linge, Willie \& Damary, (2010) disagree with such sentiments. They found that gender differences have influenced to a large extent the career growth. Burke (2007) for example argues that women are stereotyped to take care of the family and hence cannot progress in their career as fast as their male counter parts. The following second objective of this study investigated the existence of any significant relationship between stipulated policy guidelines and their career progression.

\section{Stipulated Policy Guidelines and Tutors' Career Progression}

More than three quarters of the tutors sampled revealed that TSC was strictly following the stipulated guidelines. A majority of these $(57 \%)$ felt that there is need to do more on career progression policy especially the interview process. Stringent measures should be applied to seal loop holes that may facilitate corruption during promotions.

It was also found that many tutors are promoted and retained without specific assignments posed a great threat to junior officers who don't have such job groups but have internal appointments on acting capacity responsibilities. Efforts therefore could be established to ensure that those in acting capacity are in the collect job group to reduce discontent.

$\mathrm{H}_{02}$ : There is no significant relationship between perceived TSC adherence to stipulated policy guidelines and tutors career progression.

The second hypothesis focused on identifying whether a relationship existed between TSC adherence to stipulated policy guidelines and tutors career progression. Linear regression analysis was used to test the relationship between adherence to set policy guidelines by TSC and tutors career progression. The results show adjusted $\mathrm{R}^{2}$ of .56 which shows that only $57 \%$ of variance in tutor's career progression in PTTCs accounted for by TSC adherence to stipulated policy guidelines. TSC adherence to stipulated guidelines ( $B$ $=.753, \mathrm{t}=16.4, \mathrm{p}=0.00$ ) were statistically significant. The study concluded that adherence to set policy guidelines by TSC positively influences tutors career progression. 
Table 2. Relationship between TSC perceived adherence to stipulated policy guidelines and tutors' career progression.

\begin{tabular}{|c|c|c|c|c|c|c|}
\hline \multicolumn{2}{|c|}{ Model } & $\begin{array}{c}\text { Sum of } \\
\text { Squares }\end{array}$ & Df & $\begin{array}{c}\text { Mean } \\
\text { Square }\end{array}$ & F & Sig. \\
\hline & Regression & 7249.223 & 1 & 7249.223 & 268.911 & .000 \\
\hline & Residual & 5526.323 & 205 & 26.958 & & \\
\cline { 2 - 7 } & Total & 12775.546 & 206 & & & \\
\hline \multicolumn{7}{|c|}{ Predictors: (Constant), TSC adherence to stipulated policy guidelines } \\
\hline \multicolumn{7}{|c|}{ Dependent Variable: Career progression } \\
\hline
\end{tabular}

\section{Exposure to Professional Development and Career Progression of Tutors}

Fifty one percent of tutors agreed that there was good professional development exposure of tutors teaching in Primary Teacher Training Colleges in Kenya. The study also revealed that $42 \%$ of the tutors sampled have not attended any in-service course since joining college. This is very worrying since teacher training requires constant refreshing of skills so that colleges train primary teachers responsive to the dynamic and changing society. Besides, the study revealed that few tutors $(5 \%)$ are specifically trained to teach in PTTCs at the University. This confirms findings by Thuranira (2010) on the need for In - service training of teacher trainers.

$\mathrm{H}_{03}$ : There is no significant relationship between tutors' exposure to professional development and their career progression.

Table 3. Tutors' exposure to professional development programmes and their career progression.

\begin{tabular}{|c|c|c|c|c|c|c|}
\hline \multicolumn{2}{|c|}{ Model } & $\begin{array}{c}\text { Sum of } \\
\text { Squares }\end{array}$ & df & $\begin{array}{c}\text { Mean } \\
\text { Square }\end{array}$ & F & Sig. \\
\hline & Regression & 4240.961 & 1 & 4240.961 & 101.686 & .000 \\
\hline & Residual & 8534.585 & 205 & 41.632 & & \\
\cline { 2 - 6 } & Total & 12775.546 & 206 & & & \\
\hline \multicolumn{7}{|c|}{ Predictors: (Constant), Tutors' exposure to professional development } \\
\hline \multicolumn{7}{|c|}{ Dependent Variable: Career progression } \\
\hline
\end{tabular}

The third and the last hypothesis sought to find out existence of significant relationship between tutors' exposure to professional development and their career progression. The results of the analysis summarized in table, show R - Value of .576 with an adjusted R square of .329 an indication that $32.9 \%$ of career progression is accounted for by tutors' exposure to professional development programs. F - Value (101.686) was found to be significant at 0.000 (p $<$.05) showed effect of tutors' exposure to professional development on their career progression. Tutors' exposure to professional development $(\beta=.77, \mathrm{t}=8.4, \mathrm{p}<0.05)$ is statistically significant. Based on this data the researcher rejected the null hypothesis and concluded that there was a significant relationship between the career progression of tutors and their exposure to professional development programs.

\section{Discussions}

The study revealed that gender in PTTCs is evenly distributed with $52.2 \%$ being male and $47.8 \%$ comprising female tutors. This could possibly imply that many colleges are accessible therefore attracting both gender in equal measure. Promotion trend is expected not to show gender differences since both gender have equal opportunities.

Tutors gender test on career progression produced no differences with Chi - square test. Cramer's V - value (0.426) showed weak relationship between tutors gender and career progression. This implied that there was no significant relationship between tutors gender and their career progression. Majority of policy documents on education and gender recommends entrenching gender and plans to ensure parity (Constitution of Kenya, 2010; UNESCO report, 2004; ILO, 2004 and World Bank report, 2006). This effort in reducing gender gap seems to be bearing fruit in PTTCs in Kenya since its evident that more women are in leadership positions and in fact in key positions of Chief Executives (Principals) of the colleges. The study found that out of the 16 colleges sampled only 8 were women Principals and out of the five sampled Deans, three were men and two were female Deans. This was a clear indication that no gender was preferred when TSC was promoting its staff and that the third representation outlined in the constitution of Kenya is met. This finding was in inconsistent with what Mwamwenda (2004) found in South Africa that women did not go for leadership position even after salary increase since they were not satisfied with promotion process. Complexities of making choices of career and managing home were cited by female tutors who said that men are more mobile. This also did not agree with Kegonda (2010) who found that although promotion were open for all, most (69\%) of district officers and head teachers in Uganda were male which could be a possible cause of delayed career progression among female tutors, especially for young mothers who prefer taking care of the young ones in Uganda. This also contradicted findings by Wanjama (2002) and Mwangi (2011) in Kenya, who found that women teachers have conflicts between career and household responsibilities hindering their career advancement. PTTCs in Kenya seems to be going away from the traditional gender stereotype that female teachers are confronted with challenges such as socialization, gender roles and discrimination in the work place.

The study established that there is an effect on career progression by tutors' exposure to professional development programs. This implies successful implementation of tutor professional development to is influencing tutors career progression. However, it is worth noting that variation of responses for tutor professional development is rather high. This variation possibly arises because tutors as employees naturally judge financial management according to how the managers respond to their individual and departmental demands for funding rather than how scarce resources are used to meet prioritized goals in tutor professional 
development. That notwithstanding, all tutors sampled felt that the In service training (INSET) they have experienced so far had a positive contributing to their professional development and hence career progression. Among those very strong on this are those who have been attending Strengthening Mathematics and Science Education (SMASE) INSET who said that the skills learnt helped the syllabus coverage. The certificate issued in these training also was recognized by TSC.

Tutors need to have opportunities to update their subject knowledge and teaching skills throughout their career. They need to have opportunities to exchange ideas and best practice with other tutors in the profession for optimum class performance. In so doing, they increase their accountability for their success in sustaining and raising achievement levels of their students. This in the long run increase tutors chances of career progression. Responding to the question "has professional development helped you to progress in your career?" tutors had varied responses; $3 \%$ of the respondents said that professional developments could help them to have intrinsic value. Another group (15\%) felt that professional development help them to progress in their career starting from the classroom. Only $82 \%$ said that professional development help them to progress in their career. The figures show the importance of professional development to career progression of tutors. These findings were consistent with finding by Hughes (1991) who pointed the need for professional development of tutors for career performance.

The relationship between TSC adherence to stipulated policy guidelines and tutors' career progression produced a strong positive relationship. The study indicated that overall, PTTCs and TSC are adhering to stipulated policy guidelines. From the interviews, the research found that though there is no college currently doing succession planning, there is need to involve principals more in the appointment of tutors from within. Hall (1996) found that the purpose of human resource management in schools is to get the best from teachers in order to achieve schools strategic goals in an effort to improve opportunities. She argued that this autonomy gives schools the freedom to choose the value system of the school. This value system should be supportive of individual teachers' career progression and established institutional progression plan. The study acknowledges that TSC has put effort in the implementation of career policies in PTTCs. It is clear that the changes which have been made by TSC to promote on the basis of where the vacancy arises has been critical in removing previous inequalities emanating from few vacancies in colleges.

\section{Conclusions and Recommendations}

The findings of this study are of particular importance to organizations especially in Public Teacher Training Colleges (PTTCs) in Kenya. The study concluded that tutors' gender did not have any significant relationship with career progression. However, exposure to professional development and adherence to policy guidelines by TSC influenced career progression positively, which is positive result for this study.

Kenya's effort of ensuring increased opportunities for secondary school leavers through pre-service training in PTTCs has been largely a success. However, its effort in enhancing career mobility of college tutors has scored very poorly. In particular, there has been increase in gender equality of tutors for good performance and further studies. However, the promotion opportunities remain very low due to scarcity of funds and appointive positions in PTTCs. The researcher recommends that promotion policies in PTTCs be flexed so that certain vacancies are created and reserved for tutors teaching in PTTCs. An example of such position is TSC substantive examinations officer, Assistant Deans, (Head of Department (HOD) performance contract, Examinations officer and others that will increase chances for career growth for the tutors.

Based on the findings, the study recommends that TSC should conduct a base line survey to establish the needs of tutors in terms of;

- TSC policy on interview

- Posting of tutors who have high job groups and have failed in administrative duties elsewhere

- Stagnation of tutors in job group L and M

Finally, feedback from TSC featured heavily in the responses especially after the interview. After the stress that the tutors undergo in the preparation for an interview with $\mathrm{TSC}$, it is only fair that they receive honest opinions from the interview so that they are more equipped in future. The study therefore recommends that TSC should develop a system of communicating results of the interview so as to make unsuccessful applicants more confident to apply advertised position in future.

\subsection{Suggestions for Further Research}

The study suggests the following recommendations for further research;

This study could be replicated elsewhere including other tertially institutions or Universities to verify its findings.

The relationship between career progression and turnover of tutors has not been examined in this study. It is proposed that qualitative or quantitative study that examines how closely career progression and tutor turnover are may be done.

There is need for another study to be conducted to establish the needs of tutors in relation to information disseminated to tutors necessary to promote tutor satisfaction through career progression.

\section{REFERENCES}

[1] Armstrong, M. (2009). A handbook of Human resource 
management practice; 10th_edition. London: Kogan

[2] Ballout, H.I. (2009). Career commitments and career success: Moderating role of self-efficacy. Career Development International, 14(7), 655-670. http://dx.doi.org/1o.1108/136 20430911005708

[3] Brown, G., Brown, J. \& Sumra, S. (1999). The East Africa Madrasa programme; The Madrasa resource centres and their community-based preschool programme. Evaluation report prepared for the Aga Khan Foundation.

[4] Burke, R. J. (2007). Career Development of Managerial Women: Attracting and Managing talent. In Bilimoria, D. \& Piderit, S. K. (Eds.), Handbook on women in Business and Management. Cheltenham: Edward Elgar Publishing Limited.

[5] Cheramie. R.A., Sturman, M.C., \& Walsh, K. (2007). Executive career management: Switching organizations and the bounderyless career. Journal of vocational Behaviour, 71, 359-374. http://dx.doi.org/10.1016/j.jvb.

[6] CIPD (2006). Reflections on talent management. Available at http://www.cipd.co.ku/subjects/recruitment/general/-rtitintm gt.htm

[7] Gallos, J. (1989). Exploring women's development; Implications for theory, practice and research. In M. B. Arthur, D. T. Hall \& B. S. Lawrence (Eds.), Handbook of career theory (pp. 110-132). Cambridge: Cambridge University Press.

[8] Goodland J. (1984). A place called School. New York: M.C Graw Hill

[9] Hall, D.T. (1996). The career is dead. Long live the career. San Fransica: Jossey Bass.

[10] Hakim, C. (2006). Women, Careers and work life preferences. British Journal of Guidance and Counseling, Vol.34, No.3, August 2006.

[11] Kagonda, A.M. (2010). Determinants of career professional development of female teachers in Uganda: Empowering women in leadership journal. Retrieved from www.hst.coehs.unosh.eduposp2004articles/kagonda on 25th March 2012.

[12] Lacey. K (2001). Succession planning in education. Australia council for education Administration Hot Topics, No. 4 Sept.

[13] Lacey, K. (2004). Women in teaching: Factors that impact their leadership aspirations. IARTV seminar series number 131. Melbourne: incorporated Association of Registered Teachers of Victoria.

[14] Linge,T.K., Willie,V. \& Damary, S. (2010). The role of visibility and career advancement of women in Kenya: The journal of language, Technology and Entrepreneurship in Africa, Vol 2. No. 1, 2010.

[15] Lunenburg, F. (2011). Self-efficiency in the work place: Implications for motivation and performance. International Journal of Management, Business Administration, 14(1)

[16] Miles, M. \& Huberman, A.M. (1994). Qualitative Data Analysis. Thosand OAKs, CA: Sage publications.

[17] MOEST. (2005). Kenya Education Sector Support Program
2005- 2010. Delivering Quality Education and Training to all Kenyans. Nairobi: MOEST.

[18] Mugenada O.M. \& Mugenda, A.G. (2003). Research methods: Quantitative and Qualitative Approaches. Nairobi: ACTs press.

[19] Mugo, J. W. (2011). An Examination of Factors Influencing Employee Turnover. A Case of Teachers Service Commission Teachers in Public Secondary Schools in Kirinyaga District, Kenya. Unpublished MBA thesis, Kenyatta University.

[20] Mwamwenda, T.S. (2004). Job satisfaction in salary and promotion for secondary school teachers in Eastern Cape, South Africa. Journal of Education, vol: 87, issue: 1 page 93 - 94. Retrieved from http://www.ecdoeresearch.gov.za on 6 September 2013.

[21] Mwangi, J. W. (2011). Determinants of gender imbalance in Education Administration among Teachers in Public Secondary Schools in the Larger Thika District in Kenya. Kenyatta University. Unpublished MEd thesis.

[22] O'Reilly, C., \& Chatman, J. (1986). Organisational commitment and psychological attachment: The effects of compliance, identification, and internalization on pro-social behavior. Journal of applied Psychology, 71(3),492-499, http://dx.doi.org/10.1037/0021-0110.71.3.492

[23] OECD. (2009). The professional development of teachers. Retrieved from http://www.oecd.org/berlin/4351636.

[24] Okurame, D.E. (2012). Impact of career growth prospects and formal mentoring on organization citizenship behavior. Leadership and organizational Development Journal, 33(1), 66-85. http://dx.doi.org/10.1108/014377312119324

[25] Powell, G. N. \& Butterfield, D. A. (1994). Investing the Glass Ceiling Phenomenon: An empirical study of actual Promotions to top Management. Academy of Management Journal, 37 (1), 68 - 86. http://dx.doi.org/10.2307/256770.

[26] Republic of Kenya (2010). Constitution of Kenya. Nairobi: Government Printers.

[27] Smollin,M. (2011). Five reasons why teacher turnover is on the rise. Found in www.tekepart.com/article/2011/08/09/ five reasons teacher turnover is on the rise Singleton. R.A (1993). Approaches to social research. New York: Oxford University Press.

[28] Teachers Service Commission. (2002). Operational manual on Teacher Recruitment. Nairobi: Jomo Kenyatta Foundation.

[29] Teachers Service Commission. (2007). Policy on identification, selection appointment, deployment and training of heads of post primary institutions, Feb. 2007

[30] Teachers Service Commission (2009). Employee / customer satisfaction survey by Tetralink Taylor \& Associates.

[31] Thuranira, T.S. (2010). Perspective on teaching profession in Kenya. Unpublished PhD thesis. University of Maryland.

[32] Trochim, W.M. (2009). The research methods Knowledge, $2^{\text {nd }}$ edition. Retrieved from URL: $<$ http://trochim.human.cor nell.edu/kb/index.htm $>$. On $5^{\text {th }}$ July, 2010.

[33] UNESCO. (2004). Role of men and boys in promoting Gender equality - Advocacy brief. Bangkok: UNESCO 
[34] Uwezo. (2011). Annual performance assessment report. Retrieved from http://www.uwezo.net/wp.content/uploads/2 012/08/ke - 2011 on 16th December 2013.

[35] Wanjama, L. (2002). Factors Influencing Gender Mobility to the Top Levels of Education Management in Kenya. Kenyatta University. Unpublished Doctoral Dissertation.
[36] Weer, C. H. (2006). The impact of non - work role commitment on employees' career growth prospect. Retrieved from http://idea.library.drexel.edu/bitstream/1860 /1165/1/weer_christy.pdf

[37] Zinn, L. (1997). Supports and Barriers to teacher leadership: Reports of teacher leaders. Paper presented at the annual meeting of the American educational research association. 